\title{
The Effect of Using Hard Landscape Material on Thermal Environment (A Case Study on Malioboro Street)
}

\section{Supriyanta ${ }^{1}$ and Muhammad Ginanjar ${ }^{2}$}

\author{
${ }^{1}$ Department of Architecture, Islamic University of Indonesia, Yogyakarta \\ ${ }^{2}$ Department of Architecture, Islamic University of Indonesia, Yogyakarta
}

\author{
Article History \\ Received : 19 March 2019 \\ Accepted : 25 March 2019 \\ Published : 01 April 2019
}

\begin{abstract}
One of the current issues of urban temperature greatly discussed is Urban Heat Island (UHI). It is a phenomenon that can affect people's level of comfort in doing outdoor activities with respect to the rising of air temperature. There are many factors that affect the occurrence of UHI. One of them is the increasing use of hard landscape materials. This research was conducted to find out how big the influence of the use of hard material of the landscape on the decrease of outdoor environment temperature. The sample selection was taken on the research site, namely Malioboro Street, Yogyakarta, through the simulation of temperature evaluation using the Envi-Met software. The landscape materials studied include brick road (red stone) / red brick, sandy soil, asphalt road, dark concrete pavement, concrete pavement gray, and dark granite pavement. Then, each object of the study was tested and compared to determine the most optimal landscape component in the thermal environment degradation. From the results of the simulation test conducted through Envi-Met software, the change of thermal condition in each material can be identified. The difference in the changes that occurred between the materials tested was not quite significant. The hard landscape material that absorbs heat the least, and thus causing the largest thermal temperatures is the brick material, while the environment with the lowest thermal conditions use sandy soil material.
\end{abstract}

Keywords: Landscape material, Thermal environment, Urban Heat Island

\section{Introduction}

The development of a city can be seen from the population growth, which is followed by the improvement of the quality of urban infrastructure. This development leads to the transfer of green open space functions into constructed land such as housing, offices, shopping centers, and others. One of the impacts resulted from reduced green open space is the increasing temperature of the area or the influence of urban heat island. The changing surface of the city by humans produces a diverse microclimate that has a collection effect reflected by urban heat island (Landsberg, 1981 in McPherson, 1994). Urban Heat Island is the term for a state in which

Correspondence: Supriyanta

Department of Architecture, Islamic University of Indonesia, Yogyakarta

E-mail: supriyanta@uii.ac.id the temperature in urban areas is higher than the surrounding periphery. The main cause of heat island is the modification of the earth's surface due to the development of a city that uses materials that can absorb heat. The solar heat is stored through "impervious engineered surfaces" during the day, and the heat is released into the atmosphere at night (Howard, 1881). According to Sulistyantara and Yoritaka (1995), buildings and pavements such as asphalt roads contribute greatly to surface temperatures, reaching $56^{\circ} \mathrm{C}$, whereas in urban green areas, the temperature is stable at $<35^{\circ}$ C. This issue encourages the authors to conduct a study by simulating and comparing the use of the hard-matter elements of the landscape to determine the difference in thermal conditions of each material in the area tested using Envimate software This study was conducted on Malioboro Street because it is in a crowded urban area. This study aims to determine the effect of landscape hardness / hard material on the thermal changes of the environment. 
The Effect of Using Hard Landscape Material on Thermal Environment (A Case Study on Malioboro Street)

Supriyanta, Muhammad Ginanjar

\section{1}

This research is expected to provide benefits in environmentally sound development plan so that the quality of environmental comfort can be increased.

\section{Formulations of the problem}

1. Can landscape elements affect changes in both environmental and thermal elevations?

2. How big is the permanence of each landscape element tested against thermal in Malioboro Street area? What are the best landscape elements for environmental thermal changes?

\section{Research Objectives}

1. Recognize the effect of landscape elements on changes in both environmental and thermal elevations.

2. Determine how large the flight of each landscape element is tested against thermal in the Malioboro street area.

3. Identify what landscape elements are especially suitable against environmental thermal changes.

\section{The scope of research}

1. Spatial Space Scale: Micro. Scope: Building components. Local potential: Selection of landscape elements is good for environmental thermal.

2. Substantial Spaces Scope: Analysis through simulation

\section{Benefits of research}

The result of the research is thermal data on each hard material usage that has been compared to each other, in order to find out the influence of pavement dominated area to temperature change. This research is expected to provide benefits in environmentally sound development plan so that the quality of environmental comfort can be improved.

\section{Research Methods}

\section{Data Collection Technique}

a. Literature method

Literature method is a method of collecting data by looking for references through various print media such as books, magazines, brochures, newspapers and information-related papers that support research.

\section{b. Desk Study Method}

Desk study method is a method of collecting reference data through internet media. The consideration is to assume the power and validity of the information to be carefully considered. The author uses this method for use as additional information not at the core of the discussion, and searches for information from reliable sources.

\section{c. Observation Method}

Observation method is a method of collecting data that is done by observing the object directly in the field. Through this research method, information obtained are clearer and more accurate because based on the researcher's direct observation, so the research variables can be identified in detail.

\section{d. Documentation Method}

Documentation method is a method of collecting data in the form of images / photographs taken from research. Methods are used to strengthen the research to be made.

\section{Data Analysis Technique}

The method used is a quantitative method that is detailed, specific and determined from the beginning. This method aims to show the relationship between variables, which has a predictive value using experimental research techniques, surveys, and observations, the resulting data in the form of quantitative descriptions and measurement results based on variables used with a research process through simulations using computer software that knows the effect of landscape elements on environmental thermal changes.

\section{Theoretical Foundation}

\section{Malioboro Area}

Malioboro Street is the name of one of the three streets in Yogyakarta City that stretches from Tugu Yogyakarta to the crossroad of Post Office Yogyakarta, consisting of Pangeran Mangkubumi Street, Malioboro Street, and Jend. A. Yani Street. This street is the axis of Imaginary Line of Kraton Yogyakarta. Malioboro area is one of the most famous tourist area in Yogyakarta City. Its charm is not only known 
by local tourists, but also by foreign tourists who often visit the tourist site. Malioboro is the center of various activities, ranging from trade and services, community services, tourism, and social culture and home to many communities. The Regional Spatial Plan of Yogyakarta stated that the area of Malioboro is a strategic citrakota area. Citra Kota Yogyakarta is an image attached to the city of Yogyakarta that reflects aspects of education, struggle, tourism, and services based on culture. The Maliboro area is in a fairly crowded urban area. Not only the buildings, the area is also crowded with tourists and traffic. This is what encourages researchers to do a simulation to find out how much influence the use of materials, especially hard landscape material to environmental thermal condition.

\section{Definition of Urban Heat Island}

Urban Heat Island (UHI) is a characteristic of urban heat compared to non urban areas. In general, UHI refers to an increase in air temperature, but can also refer to the relative heat of the surface or sub-surface material. $\mathrm{UHI}$ is a dismay of climate change, due to modification of the atmosphere and surface in urban areas. UHI has important implications for human comfort, urban air pollution, energy management, and urban planning. UHI in hot climates is very unfavorable because it causes more energy to run out to cool, increases human discomfort, and increases the concentration of air pollution. The high level of urbanization in developing countries means that the number of people to be affected by UHI will increase (Voogt, 2002).

Figure 1. Urban Heat Island Graph

Source:(http://geography.name/urban-heat-island/ accessed on April 11, 2017, 11:11 pm)

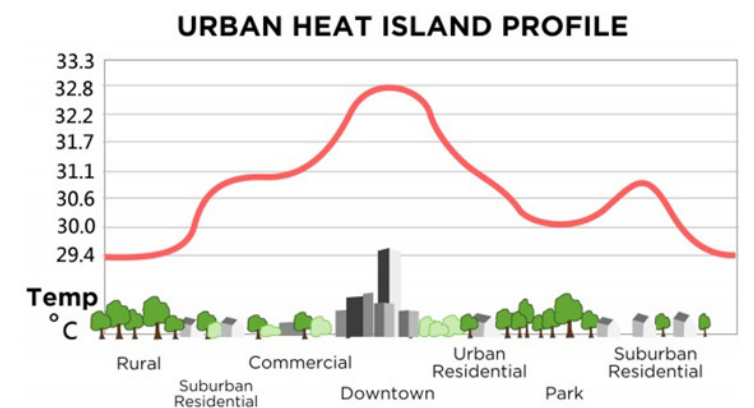

\section{Contributing Factors and Impacts}

\section{Urban Heat Island}

The presence of $\mathrm{UHI}$ in urban areas is increasing in number in each city and the increasingly differentiated value of materials between urban and suburban / rural areas can cause some effects. Voogt (2002) points out that the formation of Urban Heat Island is influenced by surface characteristics and atmospheric conditions. Direct heat additions to the atmosphere through human activities, known as anthropogenic heat, can play an important role in UHI formation.

Other contributing factors of UHI are described in more detail as follows.

1. Surface Geometry. Surface geometry means the obstruction of the sky by buildings and other objects on the urban surface expressed as a sky view factor. The addition of surface geometry and trapping of solar radiation by multiple reflections triggers heating due to greater sunlight absorption. In addition, adjacent buildings reduce the sky view factor and reduce radiative heat loss, especially at night. Surface geometry can also cause a sheltering effect that reduces convective heat loss from surface and air near the surface.

2. Thermal surface properties. Urban building materials have better heat storage. Solid and wet materials such as metal, rock, saturated clay soil, is very easy to absorb and release heat (large $\mu$ ). This material has a higher heat capacity and greater surface for thermal insertion. Dry and less dense materials with good insulator capabilities such as wood, sand or hollow concrete have smaller $\mu$ values. Model and observation simulations suggest that the heat island of a wet tropical city is expected to be small due to the magnitude of $\mu$ values in the rural area, whereas in tropical drylands, it has a larger heat island.

3. Surface conditions (drought, snow cover). Water-resistant urban building and paving reduces evaporation; more energy is directed to a sensible heat that can heat air than latent heat (heat taken for water evaporation). During the snow cover period, embankmenting of the city's surface and the addition of soil to the urban snow cover 
may increase the absorption of radiation in the city.

4. Anthropogenic Heat. It refers to heat released by urban energy used in buildings and vehicles and also from humans.

5. Urban Greenhouse Effect. The polluted and hotter urban atmospheres secrete excessive thermal radiation downward toward the surface of the city.

6. Wind and Cloud. The strongest UHI can be observed when the sky is clear and the wind is steady. The bright sky enhances rural cooling by allowing for the loss of radiative heat into the relatively cold night sky. As wind speed increases, turbulent mixing doubles reduce the temperature difference in the air near the surface. The atmospheric humidity acts like a cloud by reducing the radiative cooling of the surface potential. High atmospheric humidity will reduce the intensity of heat island.

In addition, according to a study, , there are several factors that increase urban heat (Zoer'aini, 2005), namely: surface material, surface shape and orientation, heating sources, source of moisture; air quality, and maximum heat source.

\section{Landscape Elements}

According to Hakim (2003), there are two large pieces of landscape material, namely soft materials and hard materials.

Soft Material consists of plants, which can be grouped into two types based on the leaf mass, namely: a. Plants that deciduate the leaves (Decidous plants); and b. Plants that are green throughout the year (Evergreenconifers). Plants that abort the leaves are plants that change the shape or color of the leaves in accordance with the season. After the summer ends, the leaves fall, while ahead of the rainy season, the leaves grow bushy or vice versa, e.g. flamboyant (Delonix regia), angsana (Pterocarpus indicus), or Gymnospermae species. The plants are leafy throughout the year and produce flower throughout the season, leaving no leaves.

Hard Materials are divided into 5 (five) major groups namely: a. Natural hard materials (organic materials), such as rocks, sand, and bricks; b. Natural hard materials from geological potential (inorganic materials used in their natural state), such as rocks, sand, and bricks; c. Inorganic materials used in highly modified state, such as aluminum, iron, bronze, copper, steel, and others; d. Synthetic materials, such as plastic or fiberglass; and e. Composite materials, such as concrete and polywood.

The hard materials of the landscape to be studied are as follows: Dark Granite Pavement, Brick Road, Sandy Soil, Asphalt Road, Concrete Pavement Dark, Concrete Pavement Gray.

\section{Research Methodology}

\section{Research Site}

Malioboro Street was selected as the location of the study, because it is located in a fairly crowded urban areas, which is also an attraction packed by tourists. A thoughtful consideration in selecting the landscape materials is needed to improve the comfort of thermal environment in Malioboro Street.

Figure 2. Malioboro Street, Yogyakarta

Source: (https://www.google.com/maps/accessed on June 11, 2017, 14:40 hrs

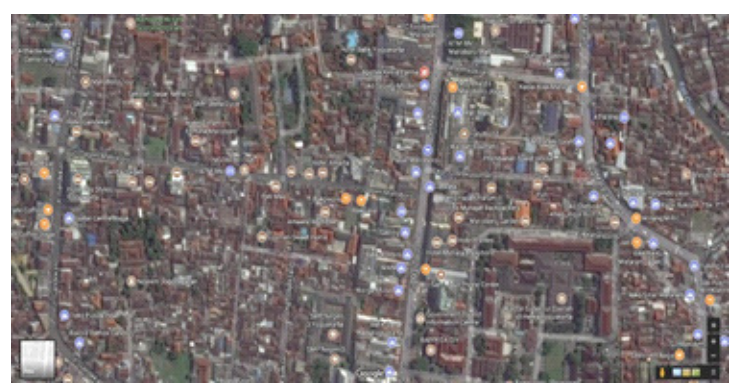

\section{Materials and Research Tools}

\section{Envirometer}

Envirometer is a tool to measure environmental conditions including air temperature, sunlight and air humidity. Data needed in this research are wind speed and outside air temperature.

\section{Anemometer}

Anemometer there is a wind speed gauge.

\section{Building Data}

Building data required in this study is the height and extent of the building. This data is used when performing the analysis process through envi-mate software.

\section{Camera}

Cameras are used to document observations from direct surveys at research sites. 
5. Envi-met Software

The analysis was performed using Softawre Envi-mate.3.

\section{Sample Population and Sample Determination Method}

In this study, the use of landscape hard material was analyzed using brick road (red stone) / red brick, sandy soil, asphalt road, dark concrete pavement, concrete pavement gray, dark granite pavement. Maliioboro Street was selected to to take the sample because the it is located in a fairly crowded urban areas.

Figure 3. Malioboro Street, Yogyakarta Source: Author data, 2017

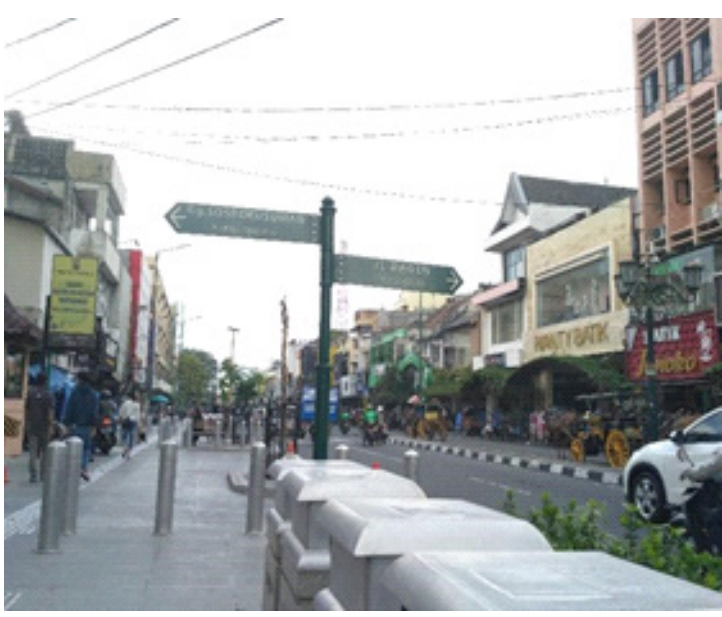

Method of Making the Research Model

1. Existing data of the research location is a comparable variable against testing the use of different materials. This research was conducted with $538 \mathrm{~m}$ long, ranging from T-junction Representative up to the intersection of Pajeksan and Suratmajan streets.

Figure 4. Malioboro Street, Yogyakarta

Source: (https://www.google.com/maps/ accessed on June 11, 2017,14.40 WIB)

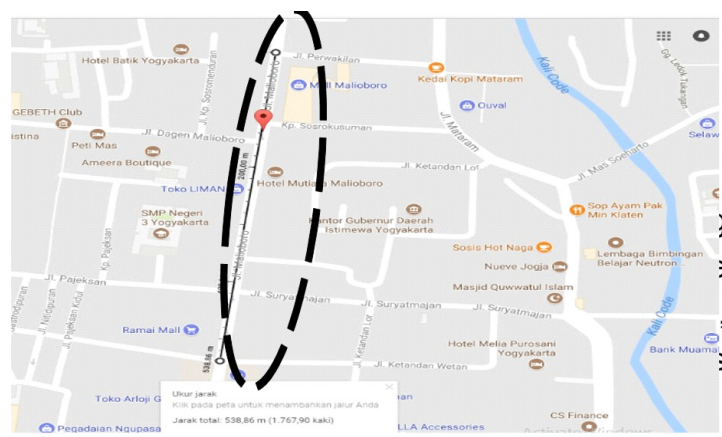

2. The process analysis was performed using Envimate Software. The required data include the temperature, humidity, wind speed, location, coordinate position, area and height of building as the main variables for testing.

3. Existing data obtained were the main parameters in the simulation process. The data was then inputted into the Envimate software to continue the rendering process to get the temperature value on the existing data based on the surface object used.

4. Results

a. After the simulation process using envi-mate software was performed, the temperature value of area tested was obtained.

b. Then, the value of each temperature of the material use was compared to each other.

c. In conclusion, this research was able to identify the best landscape material to lower the temperature in the outdoor environment.

\section{ANALYSIS AND DISCUSSION}

\section{Measurement Data}

The data required for this study is the outdoor space data on Malioboro Street, including air temperature, air humidity, building height, and wind speed. These data were obtained both from direct survey in the field and the weather data on the internet (BMKG). The data used as a simulation media was the average sum of survey data and data from BMKG Yogyakarta city.

The above data was then taken to be inputted into Envi-met simulation, with the maximum temperature of 31 degrees Celsius, and the minimum temperature of 19 degrees Celsius, and maximum humidity of $90 \%$ and minimal humidity of $55 \%$.

\section{Process Analysis Model}

There are some steps that must be done in the rocess analysis in this research, i.e.: 1. Process location data as simulated zoning reference. 2. Create basic data from Envi-met. 3. Load the simulation model using plugin space. 4. Create the initial simulation data using the plugin wizard. 5. Enter the initial simulation data into Envi-met simulator. 6. Enter data analysis to the Leonardo plugin.

1. Process location data as simulated zoning 
reference. Location data about the location conditions and surrounding buildings were made to serve as a modelling simulation plot in the Envi-Met software.

Figure 5. Malioboro Street Source: author data, 2017

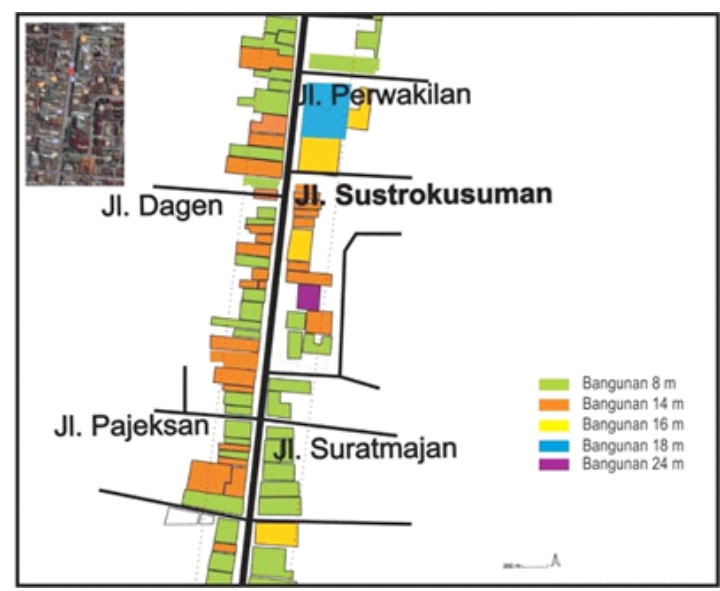

2. Create basic data from Envi-met. The first step was to manage data and settings.

Next, workspace was made according to the number of hard materials to be tested. The author made 6 workspaces for Brick Road (BR), Sandy Soil (SS), Asphalt Road (AR), Concrete Pavement Dark (CPD), Concrete Pavement Gray (CPG), Dark Granite Pavement (DGP).

3. Load the simulation model using plugin space.

Before doing the analysis, first a test area was created inside the plugin spaces.

In the Basic Setting Plugin of the new area, there are several parameters that were replaced among others. To determine the size of the grid cell in meters, the author used the grid of $\mathrm{dx}=$ $20, d y=20, d z=1$ (base height) or $20 \times 20 \times 1 \mathrm{~m}$. Then the location on earth was determined. The location of this research was in Yogyakarta, so the selected location in column name of location is Yogyakarta / Indonesia. Next, the coordinate position on Earth, was determined, namely Malioboro street with latitude -7.79 and longitude of 110.37 .

The image above is the existing test area (Malioboro Street) that has been redrawn on the spaces plugin by testing each material.

4. Create the initial simulation data using the plugin wizard.

\section{Input File Area}

Figure 6. Plugin Wizard (Input File Area) Source: author data, 2017

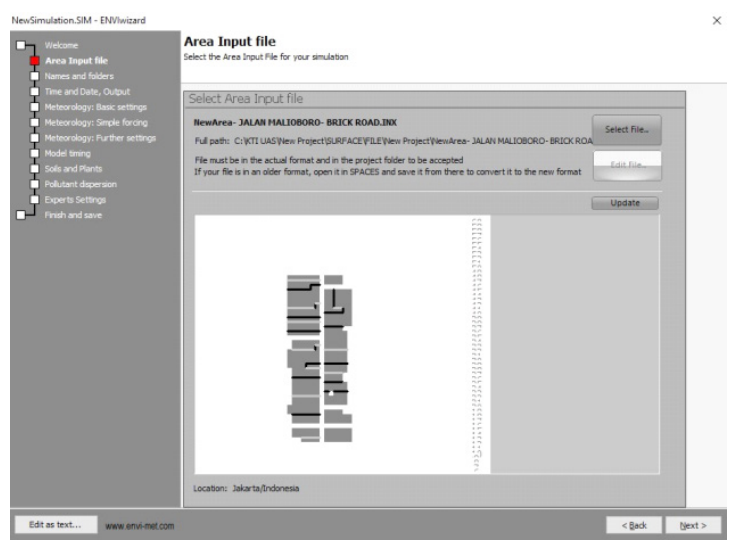

The picture above is the testing area (Malioboro Street) using the brick road material that has been redrawn on plugin spaces.

2. Names of Folders

3. Time and Date, Output

Simulation time is done at 13.00 for all test material at the same time.

4. Meteorology: Basic Setting

Average wind speed $2 \mathrm{~m} / \mathrm{s}$ toward north.

5. Meteorology: Simple Forcing

Temperature in Malioboro street: Minimum

$=190^{\circ}$ Maximum $=33.70^{\circ}$, Humidity:

Minimum $=55 \%$ Maximum $=90 \%$

6. Pollutant Dispersion

7. Experts Settings

8. Finish and Save

Figure 7. Envi-met Simulator

Source: Author's data, 2017

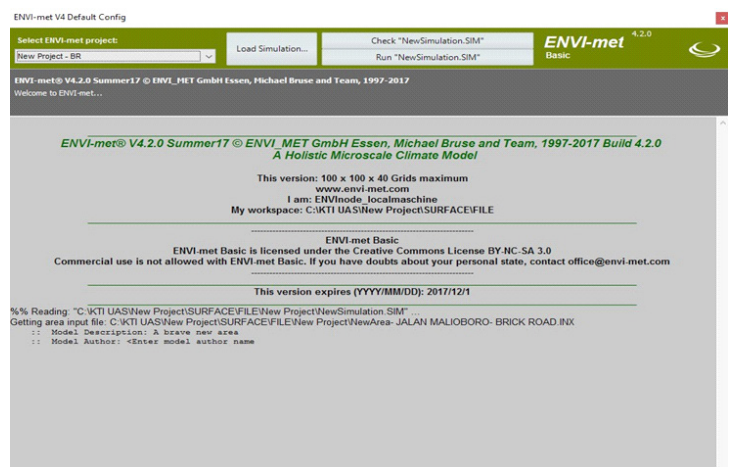

5. Enter the analysis data into the Leonardo plugin.

The data analyzed through the Envi-met simulator was then inputted into the Leonardo plugin to produce a final simulation analysis. 
The stages are as follows:

1. Input file

2. Extract $2 \mathrm{D}$ files

3. Save data

4. Discussion

The result of Leonardo's simulation is a graph of an external space temperature wave symbolized by colors, thus comparing the results of some simulated material usage.

The results of the analysis are as follows:

1. Brick Road:

Minimum temperature: $22.740 \mathrm{C}$

Maximum temperature: $24.130 \mathrm{C}$

2. Sandy Soil:

Minimum temperature: $21.37 \mathrm{OC}$

Maximum temperature: $22.400 \mathrm{C}$

3. Asphalt Road:

Minimum temperature: $21.57 \mathrm{OC}$

Maximum temperature: $22.410 \mathrm{C}$

4. Concrete Pavement Dark:

Minimum temperature: $21.570 \mathrm{C}$

Maximum temperature: $22.410 \mathrm{C}$

5. Concrete Pavement Gray:

Minimum temperature: $21.57 \mathrm{OC}$

Maximum temperature: $22.410 \mathrm{C}$

6. Dark Granite Pavement:

Minimum temperature: 21.57 0C

Maximum temperature: $22.410 \mathrm{C}$

\section{Conclusions and Suggestions}

\section{Conclusions}

Based on the results of research, it can be concluded that:

1. From the simulation test conducted through Envi-Met software, the changes in thermal conditions in each material can be identified. The difference in the changes that occurred between the materials under test is not so significant.

2. Hard landscape material that absorbs least heat and causes the largest thermal temperatures is the Brick Road material, while the material with lowest thermal conditions is the sandy soil material.

\section{Suggestions}

1. It is expected that the public should be more concerned about the special environmental thermal conditions in the urban areas, for example by using materials that can absorb heat well.

2. This research is not comprehensive yet, because there is only one aspect of the impact of the increase or decrease in ambient temperature due to the use of hard landscape material. For this reason, for the following research, those interested should discuss other aspects in depth.

\section{References}

Encyclopedia of Global Environmental Change. Chichester: John Wiley \& Sons, Ltd. 600666.

Hakim, R. (2003). Komponen Perancangan Arsitektur Lanskap. Jakarta: Bumi Aksara.

Howard, L. (1881). The climate of London. London: deduced from Meteorological observations, made at different places in the neighbourhood of the metropolis.

McPherson, E. G. (1994). Cooling urban heat islands with sustainable landscapes. In: Platt, Rutherford H.; Rowntree, Rowan A.; Muick, Pamela C.; eds. The ecological city: preserving and restoring urban biodiversity. Amherst, MA: University of Massachusetts Press: 151-171, 151-171.

Sulistyantara, B. T Yoritaka. (1995). Study on Characteristics of Green Structure at Urban Area Using the Thermoscape Analysis. Japan: Bulletin of Faculty of Horticulture Chiba University.

Voogt, J. A. (2002) Urban Heat Island, In: Douglas, I. (ed) Volume 3, Causes and Consequences of Global Environmental Change ), In: Munn, T. (ed).

Zoer'aini, D. I. (2005) Tantangan Lingkungan \& Lansekap Hutan Kota. Jakarta: Bumi Aksara. 